\title{
The Nose in Mice with Experimental Human Leprosy*
}

\author{
R. J. W. REES \\ National Institute for Medical Research, \\ Mill Hill, London NW7 IAA \\ A. C. McDOUGALL \\ and \\ A. G. M. WEDDELL \\ Department of Human Anatomy, Oxford University, \\ South Parks Road, Oxford OX13QX
}

\begin{abstract}
Normal and immunologically deficient mice inoculated with Myco. leprae (1) locally in the footpad or ear, (2) intravenously, and (3) intraperitoneally, were killed 1-2.5 yr later and their tissues examined bacteriologically and histologically. Quantitative bacterial assessments showed that by $1.5 \mathrm{yr}$ a high proportion of all animals had a countable number of bacilli $\left(>5 \times 10^{4}\right)$ in uninoculated ears, footpads or nose. Of these sites the nose on average was most frequently infected and contained significantly higher yields of bacilli. Moreover, nasal smears from a proportion of the mice showed acid-fast bacilli. Histology of the nose showed a variable number of bacilli within macrophages deep to the nasal mucosal epithelium but also bacilli within the overlying ciliated columnar-epithelial cells. In contrast bacilli were very rarely seen in the overlying squamous epithelial cells of the skin in the nasal vestibule and elsewhere, however heavily infected was the underlying dermis. These findings in the mouse are discussed. Attention is drawn to the frequent involvement of the nasal tissues and the excretion of large numbers of bacilli in the nasal mucus.
\end{abstract}

\section{Introduction}

Since 1965, systematic studies have been undertaken to follow at intervals from 6 months to 2.5 years the bacteriological and histopathological evolution of infections in mice inoculated with Mycobacterium leprae. In this period data have been collected from several hundred immunologically normal, and immunologically deficient CBA mice inoculated with some 30 strains of Myco. leprae locally in the footpad (occasionally in the ear), intravenously and intraperitoneally. The immunologically deficient mice were prepared by thymectomy followed by total body irradiation (T/900R) prior to inoculation (Rees, 1966).

Many of the general features of these infections have been published (Rees and 
Weddell, 1968, 1969; Rees et al., 1969; Weddell, Palmer and Rees, 1970). In particular they have demonstrated that there is a close resemblance between the histopathology of the disease in the mouse model and in man. They have also shown that sooner or later immunologically deficient and normal mice, inoculated locally in the ear or footpad, intravenously and intraperitoneally, develop bacilliferous and pathological lesions in particular sites, which include the nose (a site never inoculated) and the non-inoculated ears or footpads. It is on the basis of these sites of predilection, and particularly the nose because of its long-established importance in patients with lepromatous leprosy, that we now present the nasal data from experimental infections in mice.

\section{Observations}

\section{BACTERIOLOGICAL STUDIES}

Earlier studies have shown that 12 months and more after the inoculation of Myco. leprae either into the footpad or intravenously, there is systemic spread and localization of bacilli within several preferred sites (Weddell, Palmer and Rees, 1970). Following local inoculation into the footpad the preferred sites were the ear and nose, and following intravenous inoculation, the same sites as well as the footpads. To compare the relative susceptibilities of these sites for the localization and multiplication of Myco. leprae the bacteriological data from our relevant experiments were analysed. The data was based on total yields of acid-fast bacilli from weighed footpad, ear and nasal tissues, the latter being included in a snippet taken from the whole nose and upper lip, and standardised to bacillary yields per unit weight $(\mathrm{l} \mathrm{g})$ of tissue. The proportion of solidly staining bacilli (i.e. Morphological Index, M.I.) was also assessed.

A simple analysis of the data from immunologically normal or immunologically deficient (T/900R) mice in which bacilli had been inoculated into the footpad, is given in Table 1. The results show that there was systemic spread to the nose

TABLE 1

Spread and yield of acid-fast bacilli in mice after footpad inoculation of Myco. leprae

Comparison of nose and ears as sites of spread

(56 mice)

Spread to nose alone 16

Spread to nose and ear

36

Spread to ear alone

4

Analysis of relative yield of bacilli in nose and ear where both sites were infected

(52 mice)

$\begin{array}{lr}\text { Yield in nose }>\text { ear } & 38 \text { mice } \\ \text { Yield in nose }=\text { ear } & 9 \text { mice } \\ \text { Yield in ear }>\text { nose } & 5 \text { mice }\end{array}$

A verage Morphological Index

Nose 25.6

Ear 10.8 
more frequently than to the ear; where spread to both sites occurred, the yield of acid-fast bacilli as well as the M.I. were higher in the nose than in the ear. All these results were statistically significant $(P=<0.01)$.

Similar data were analysed from 26 immunologically normal or immunologically deficient mice inoculated intravenously with Myco. leprae, who at the time of killing had a countable number of acid-fast bacilli in the ear, footpad and nose. The yields of bacilli at the various sites was very variable for they were related both to time of killing after an inoculation and to the immunological competence of the individual mice. Thus a particular statistical technique was applied in order to compare the levels of infection at the three sites (see Appendix). In summary the analysis showed a highly significant difference $(P=<0.001)$ between the mean infection levels observed at the three sites. They showed that the mean infection levels recorded at the nose of each animal were significantly higher than those of the ear or footpad which did not differ significantly from each other. A sample of the counts obtained from five of the animals is given in Table 2.

TABLE 2

Representative yields of acid-fast bacilli from the footpad, ear and nose of five mice inoculated intravenously with Myco. leprae

\begin{tabular}{ccc}
\hline & Yield/g tissue \\
Ear & Nose \\
\hline $7.1 \times 10^{5}$ & $1.3 \times 10^{6}$ & $4.7 \times 10^{6}$ \\
$2.5 \times 10^{4}$ & $1.3 \times 10^{4}$ & $2.4 \times 10^{6}$ \\
$5.7 \times 10^{7}$ & $9.5 \times 10^{7}$ & $1.9 \times 10^{8}$ \\
$2.0 \times 10^{7}$ & $3.3 \times 10^{7}$ & $1.8 \times 10^{8}$ \\
$4.0 \times 10^{5}$ & $1.2 \times 10^{6}$ & $7.0 \times 10^{5}$ \\
\hline
\end{tabular}

While saline-wetted smears prepared from the surface of the footpad rarely showed acid-fast bacilli, many smears from the nose contained bacilli (Fig. 1).

\section{HISTOLOGICAL STUDIES}

These studies were routinely based on the nose-tip (snout) which included the anterior part of the vestibule. Such biopsies were obtained from 14 immunologically deficient or normal animals.

The most marked and widespread bacillation was seen in the thymectomisedirradiated group, and in most of these there was a high percentage of solid-staining organisms. Despite the differing routes of inoculation, and the range of inoculation-to-killing time (13-28 months), no significant histological differences were noted in relation to these two factors. Cellular reaction was never marked, and often minimal; when present it was mainly of histiocytes, with a few lymphocytes. Bacilli were widespread in the dermal macrophages but were also seen frequently in hair follicles, plain and striated muscle, and in blood vessel endothelium. In numerous animals solid-staining organisms were found in the endo- and perineurim of dermal nerve filaments. Bacilli were either single, in small groups, or in globi of moderate size. In a few animals where some anterior turbinate was included, the mucoperichondrium contained bacilli in isolated macrophages, in macrophages in lymphoid tissue, blood vessel endothelium, and 


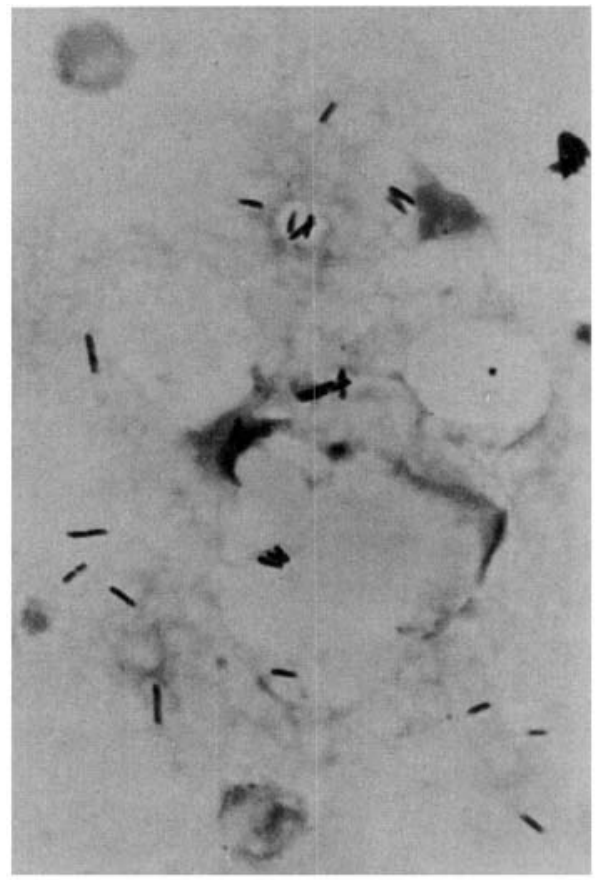

Fig. 1. Nasal smear immediately after killing. All fields contained large numbers of solid-staining bacilli. Ziehl-Neelsen, oil immersion.

nerves; bacilli were not found invading the cartilage directly. On reviewing a large number of sections from the vestibular region, no bacilli have been found in squamous epithelium or keratin, though on the hairy skin surface, one or two animals showed occasional bacilli emerging from hair follicles or vibrissae.

In the immunologically normal mice, only one, killed 24 months after inoculation, showed changes approaching in degree those just described. However, the localization of bacilli resembled those in the thymectomized-irradiated group. In these normal animals at this later stage histiocytes and lymphocytes were more frequent, and the number of bacilli in nerves of ten appeared relatively greater than in other tissue elements.

These findings suggested that much more significant histopathology might be revealed if tissues from the more posterior parts of the nose, including septum and turbinates, were taken. We therefore examined in detail the nasal tissues fixed in situ by perfusion with buffered formaldehyde from an immunologically deficient mouse 15 months after a footpad inoculation of Myco. leprae.

The findings were of considerable interest. Footpads were checked and found characteristically positive for an immunologically deficient animal on killing at 15 months, and a fairly high percentage of organisms were solid-staining. The nose tip (snout) was highly positive for bacilli, which permeated the dermis and invaded plain and striated muscle. Globi were abundant. Nerve filaments were bacillated, although not markedly so, but a very high percentage of organisms were solid-staining. The turbinates were highly positive for bacilli, but the highest 


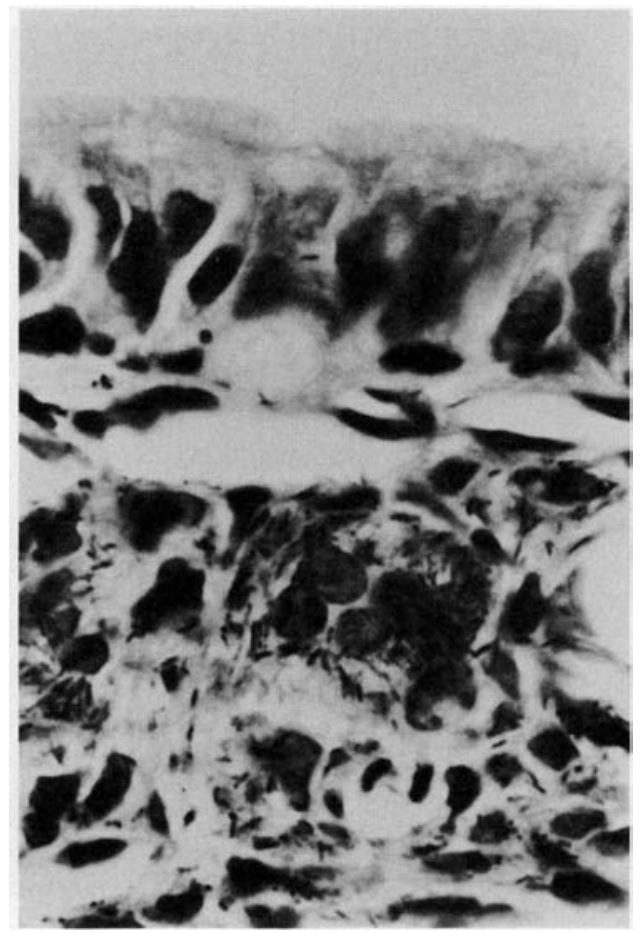

Fig. 2. Inferior turbinate; submucosal macrophages and perivascular histiocytes carry large numbers of bacilli. One (Upper centre) is seen between columnar epithelial cells, oil immersion.

concentration of organisms were in the septum, at about the level of the mid-cavity, and in an area of typical respiratory mucous membrane (Fig. 2 ). The mucoperichondrium here was full of bacilli and globi were profuse. Bacilli were seen in macrophages, fibroblasts, mucous glands, and in small filaments of the trigeminal nerves (Fig. 3). Of particular interest was the finding of bacilli in perivascular histiocytes and lining cells of blood and lymph vessels (Fig. 4). Bacilli were also seen in the basement membrane area of the epithelium, and both between and in epithelial cells apparently pursuing a course to the surface (Fig. 5). The sections did not show goblet cells too clearly, and bacilli were not in fact seen in this position. The olfactory mucous membrane revealed very few bacilli in the stroma, and they were not seen in any of the non-myelinated olfactory nerve filaments. Some bone from this area was included in these sections, and bacilli were numerous in the marrow. The Gasserian ganglion, the sensory root, and one or two other divisions were also processed, and found negative for bacilli. The nasopharynx and choanal region showed abundant bacilli, mainly in isolated histiocytes and histiocytes in lymphoid follicles.

\section{Discussion}

Since the early days of informed clinical observation in Norway and elsewhere, there have been frequent references to the importance of the nose in the spread of 


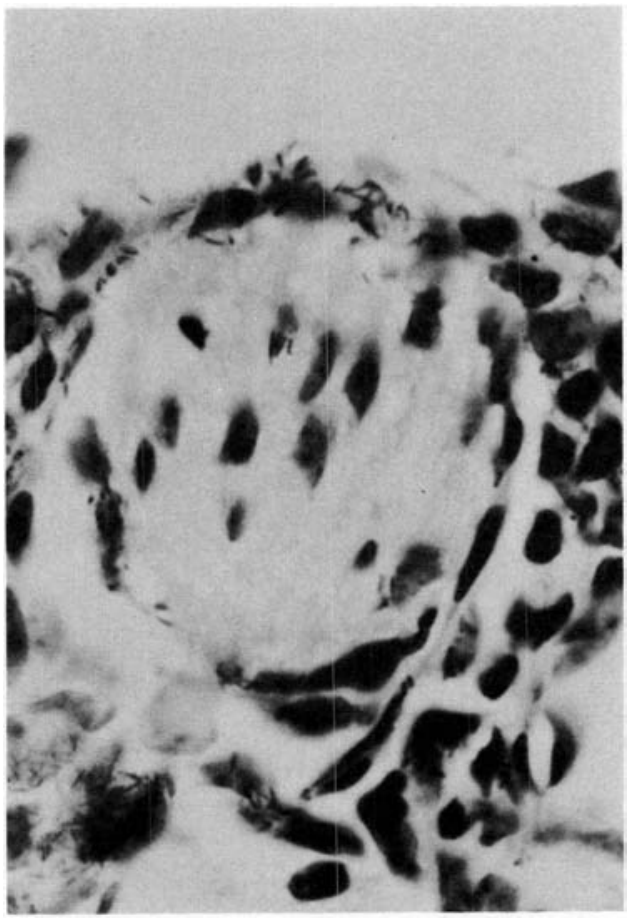

Fig. 3. Inferior turbinate; bacilli are seen in the peri- and endoneurium of a tiny branch of the trigeminal nerve, oil immersion.

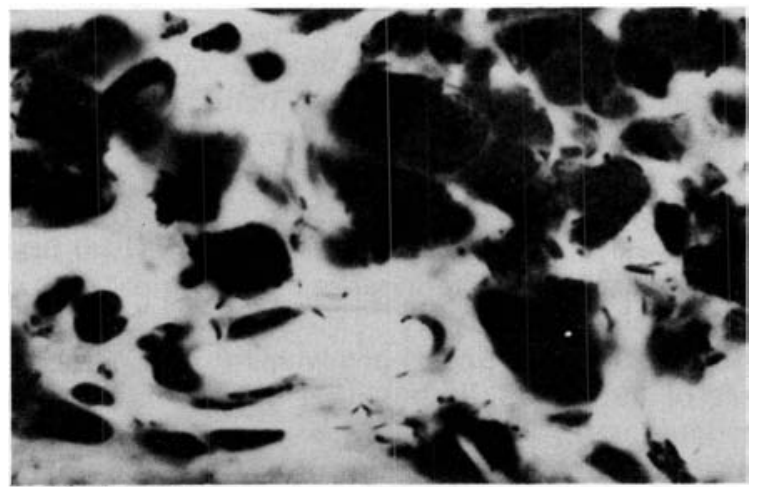

Fig. 4. Septum, mid-cavity. Above and to the right are large dense globi of bacilli. A small vessel (lower centre) has solid-staining bacilli in its endothelial lining, oil immersion.

leprosy. Most textbooks (Muir, 1921; Eggston and Wolff, 1947; Cochrane and Davey, 1964) have described changes in the interior of the nose, and emphasis has usually been given to septal perforation and cartilaginous involvement, rather than to the significance of bacilli in nasal discharges. 


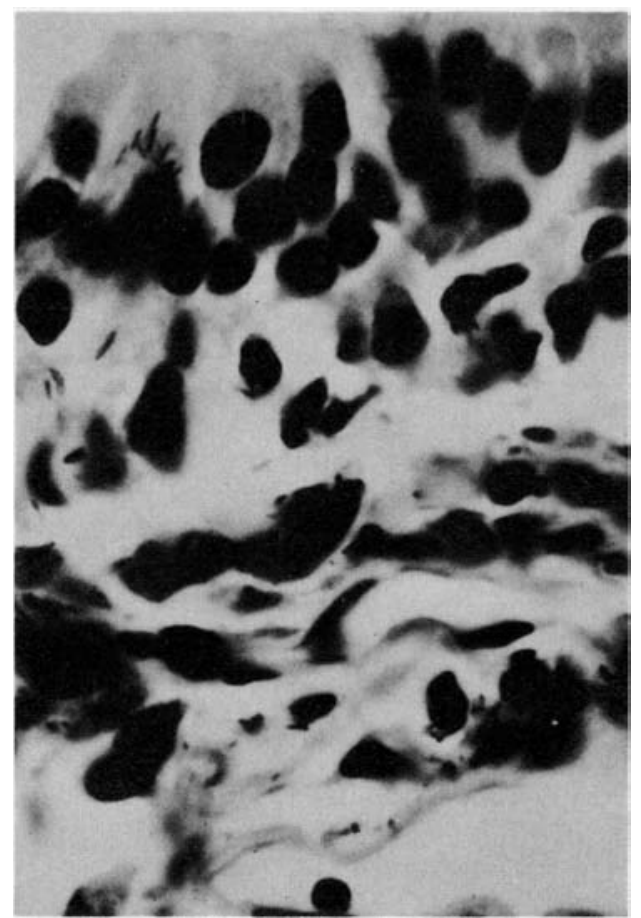

Fig. 5. Middle turbinate, mid-cavity. Bacilli (top left) are shown between, and in the cytoplasm of pseudo-stratified columnar epithelial cells, and in macrophages adjacent to a venous sinus (bottom right), oil immersion.

On the question of the value of nasal smears or scrapings, there have been suggestions that they may be either of limited value, or possibly misleading (Dungal, 1961; Padma, 1965; Arnold, 1966; Cochrane, 1971). By contrast, their value has been admirably summarised by Browne (1966), and numerous other authors have drawn attention to the clinical and public health importance of these examinations (Davey and Rees, 1973; Shepard, 1962; Bueno, 1968; Goodwin, $1967 a, b)$. In recent years, Pedley $(1970,1973)$ has revived interest in the large numbers of solidly-staining bacilli in nasal smears from patients with lepromatous leprosy, as seen in Nepal.

Our studies of the evolution of nasal involvement in experimental mice infected with Myco. leprae of human origin show that the nose is a particularly favourable site for the seeding, multiplication and excretion of viable bacilli into the environment, thus resembling the situation in man. As compared with excretion from the skin (Pedley, 1970), or in breast milk (Pedley, 1967, 1968), the nasal route is now shown to be of the greatest significance. While bacillary excretion from open lepromatous ulcers has already been shown (McDougall and Rees, 1973) to be in excess of 20 millions daily, collections of nasal mucus over $24 \mathrm{~h}$, also from lepromatous patients, have yielded counts in the region of 3.2-3.4 $\times 10^{8}$ bacilli (Rees and McDougall, 1973).

Although bacilli can be seen in vascular endothelium in lepromatous leprosy in man and in the experimental animal, we were impressed with the finding of 
solid-staining bacilli in perivascular histiocytes and in lining cells of small blood and lymph vessels. This situation resembles very closely our current findings in a large series of nasal biopsies from lepromatous patients.

The localization and multiplication of leprosy bacilli in the nose of mice in the present study adds weight to the possibility that the nose may play a more important part in the pathogenesis of leprosy than is at present believed. The model not only confirms the nose as a heavy-possibly almost continuous-exit route for bacilli, but also raises two obvious questions: (1) do Myco. leprae multiply more effectively in the nose than elsewhere and (2) is the suggestion of Sticker (1897) that the nose may be a portal of entry for Myco. leprae worthy of reconsideration?

\section{Acknowledgements}

We wish to thank Dr Umeshraya Pai, of Kasturba Medical College, Manipal, Mysore State, India, for help with the histopathology in this study, and we are grateful to Mr G. M. Wybrow for the statistical analyses. This work was supported by grants to A. C. McDougall and A. G. M. Weddell from the Medical Research Council and the British Leprosy Relief Association (LEPRA).

\section{References}

Arnold, H. L. (1966). Correspondence. Lepr. Rev. 37, 129.

Browne, S. G. (1966). The value of nasal smears in lepromatous leprosy. Int. J. Lepr. 34, 23.

Bueno, E. (1968). Primeras manifestaciones clinicas en la lepra. Experiencia personal. Actas Dermosifilog. 59, 477.

Cochrane, R. G. and Davey, T. F. (1964). Leprosy in Theory and Practice. Bristol: John Wright and Sons Ltd.

Cochrane, R. G. (1971). Correspondence. Lepr. Rev. 42, 7.

Davey, T. F. and Rees, R. J. W. (1973). The nasal discharge in leprosy. Tenth International Leprosy Congress, Session 6, 6/46.

Dungal, N. (1961). Is leprosy transmitted by arthropods? Lepr. Rev. 32, 28.

Eggston, A. A. and Wolff, D. (1947). Histopathology of the Ear Nose and Throat. Baltimore: The Williams and Wilkins Co.

Goodwin, C. S. (1967a). Histological, bacteriological and immunological differences between the bacilliferous forms of leprosy in Chinese. Lepr. Rev. 38, 171.

Goodwin, C. S. (1967b). The significance of Myco. leprae in the nasal mucosa, with special reference to Chinese leprosy patients. Lepr. Rev. 38, 181.

McDougall, A. C. and Rees, R. J. W. (1973). Ulcerating lepromatous leprosy in a patient with dapsone-resistant Mycobacterium leprae. Lepr. Rev. 44, 59.

Muir, E. (1921). Handbook of Leprosy. Cuttack, India: Orissa Mission Press.

Padma, M. N. (1965). Choice of sites for routine smearing. Leprosy in India 37, 87.

Pedley, J. C. (1967). The presence of Myco. leprae in human milk. Lepr. Rev. 38, 239.

Pedley, J. C. (1968). The presence of Myco. leprae in the lumina of the female mammary gland. Lepr. Rev. 39, 201.

Pedley, J. C. (1970). Composite contact skin smears; a method of demonstrating the non-emergence of Myco. leprae from intact lepromatous skin. Lepr. Rev. 41, 31.

Pedley, J. C. (1973). The nasal mucus in leprosy. Lepr. Rev. 44, 33.

Rees, R. J. W. (1966). Enhanced susceptibility of thymectomised and irradiated mice to infection with Myco. leprae. Nature, Lond. 211,657.

Rees, R. J. W. and Wedúll, A. G. M. (1968). Experimental models for studying leprosy. Ann. N. Y. Acad. Sci. 154, 214.

Rees, R. J. W. and Weddell, A. G. M. (1969). Transmission of human leprosy to the mouse and its clinical implications. Trans. Roy. Soc. Trop. and Hyg. 64, 31.

Rees, R. J. W., Weddell, A. G. M., Palmer, E. and Pearson, J. M. H. (1969). Human leprosy in normal mice. Br. med. J. 3, 216. 
Rees, R. J. W. and McDougall, A. C. (1973). Unpublished data.

Shepard, C. C. (1962). The nasal excretion of Myco. leprae in leprosy. Int. J. Lepr. 30, 10.

Sticker, G. (1897). Thesen über die Pathogenese der Lepra. Mitth. Verhandl. d. internat. wissensch. Lepra-Cong., Berlin 1, Abt. I, 99.

Weddell, A. G. M., Palmer, E. and Rees, R. J. W. (1970). The fate of Myco. leprae in CBA mice. J. Path. 104, 77.

\section{Appendix}

\section{ANALYSIS OF LEVELS OF INFECTION IN VARIOUS SITES FOLLOWING INTRAVENOUS INOCULATION}

Twenty-six immunologically intact or T/900R mice had a countable number of acid-fast bacilli $\left(>5.0 \times 10^{4}\right)$ in their ears, footpads and nose following an intravenous inoculation of Myco. leprae. To compare the levels of infection at these sites the following statistical technique was applied:

(1) That each individual animal has an overall level of infection A (animal).

(2) The level of infection at each site is P (site) $\times$ A (animal) when P (site) is a constant specific for each site but similar for all animals.

(3) Thus the level of infection at the 3 sites for an animal is P (footpad). A (animal); P (ear). A (animal); P (nose). A (animal).

Inspection of the data indicated that the technique was valid and for mathematical convenience the data was converted to logarithms.

A two-way analysis of variance was carried out on the data as logarithms and indicated that there was a highly significant difference $(P<0.001)$ between the mean $(\log )$ infection levels observed at the three sites.

Further examination of these mean values indicated that the mean of the log infection levels recorded at the nose of each animal was significantly higher than the mean of the log infection levels observed at each of the other two sites (the mean values for which did not differ significantly from each other). 